\title{
The Quest for Female Identity in Shashi Deshpande's The Dark Holds No Terrors
}

Shilpa Sarkar

Research Scholar

Department of English

Guru Ghasidas University

Bilaspur, Chhattisgarh, India

sarkarshilpa16@gmail.com

\begin{abstract}
Dark Holds No Terror is the second published novel of Shashi Deshpande. Saru, the protagonist of the novel is a well-educated doctor. This study is about her relationship with her parents, brother, how her life changes before and after marriage. Throughout the novel, she suffers mentally, physically and spiritually. She was a neglected child since her childhood. This paper focus on how the protagonist deal with the problems and finally discovers her real identity.
\end{abstract}

Keywords: Relationship, Marriage, Identity.

The Dark Holds No Terror is the most celebrating novel of Shashi Deshpande. This is the story about a woman who since her childhood faced gender discrimination and after marriage faced the problems with her husband. Saru, the protagonist of the novel, was modern educated and economically independent middle class Indian woman. The Dark Holds No Terror mainly focus on the relationship between mother-daughter and husband-wife. 
The novel opens with Saru visiting her father's home after a gap of fifteen years. Saru heard the news of her mother's death so she decided to visit her father's home. When she left the home she was a young girl and now she returned as a successful doctor and mother of two children. She appears to be confused here as "she was not apprehensive, though not eager either, for the moment of confrontation. She glanced back at the rickshaw in which she had come. She hadn't paid the man as yet, as if keeping a route open for retreat" (Deshpande, The Dark Holds No Terror, 15). She feels like a 'stranger'. As Sudama standing at the gate of the palace of Krishna. After a long gap of fifteen years Saru received a cold reception by her father. In her paternal house Saru gets a chance of self analysis, also gets a chance to review her relationship with her husband and with her dead mother.

Since her childhood she wanted to be treated as equal. In Indian society, male child acquires the top position, but Saru as a daughter she wanted that both Dhruva, her brother, and herself should be treated equal. The bitter experience of her childhood which gone through sex discrimination which later turned her into a revengeful daughter. She also wanted her birthday to be celebrated as her brother's birthday was celebrated. This was a cause of displeasure for her mother.

Birthdays were not then the tremendous occasions they are made out to be now; but the excitement of having one, of being center of attraction never palled. It was always a fascinating thought... I was born. But of my birth, my mother had said to me once... "It rained heavily the day you were born. It was terrible". And somehow, it seemed to me that it was my birth that was terrible for her, not the rains. (Deshpande, Dark 169).

Saru's mother always used to comment about Saru's dark complexion.” Don't go out in the sun. You'll get even darker.” (Deshpande, Dark 45) “we have to care if you don’t we have to 
get you married." And when Saru asked her mother about Dhruva, her mother replied "He's different. He's a boy.” (Deshpande, Dark 45). When Dhruva, Saru's brother, accidentally dies by drowning, Saru's mother always pointed out. "You killed your brother." (Deshpande, Dark 146). She did not miss a single opportunity to blame Saru for Dhruva's death. Through the figure of Saru's mother Shashi Deshpande draw a typical old custom, uncaring, unsympathetic, orthodox woman who always feels girl child as their burden. Sarabjit Sandhu rightly remarks:

The mother is very attached to her son. Her attitude is a typical one, after all he is a male child and, therefore, one who will propagate the family lineage. In another sense, also, the male child is considered more important than a girl, because he is qualified to give "'agni" to his dead parents. The soul of the dead person would otherwise wonder in ferment. (19-20)

Since childhood Saru's mother behaviour towards Saru was not good. As a result of it Saru became revengeful, In spite of opposition of her, mother she went for further education. The next revengeful step taken by her was to marry with Manu, a poet. When Saru informed her mother her first question was about Manu's caste. Again she cursed Saru "Let her know more sorrow that she has given me." (Deshpande, Dark 197). The beginning of Saru's married life was quite good but gradually their relationship changed. As Saru was recognised as a doctor and respected by neighbours which hurts her husband Manu. Saru earned more than Manu which hurts him the most. Saru observed " $a+b$ they told us in mathematics is equal to $b+a$. But here $a+b$ was not, definitely not equal to $b+a$. It became monstrously unbalanced equation, lopsided, unequal and impossible.” (Deshpande, Dark 42 Saru defines successful marriage: “A wife must always be a few feet behind her husband. If he's an M.A., you should be a B.A. If he's 5'4"' tall, you shouldn't be more then 5'3" tall. If he's earning five hundred rupees, you should never earn 
more then four hundred ninety- nine rupees. That's the only rule to follow, if you want a happy marriage.” (Deshpande, Dark 137).

Saru in The Dark Holds No Terrors undergoes a similar trauma like Indu in Roots and Shadows. She confronted the reality and in the end she realised that the dark she feared actually holds no terrors. Monika Khurana remarks:

"Saru is a 'two-in-one woman.' A doctor in the day time and a trapped animal at night. She wants to be free and have an identity of her own. She longs to break away from the rigid traditional norms. She hates her parental home, yet the novel begins with Saru visiting her father after a gap of fifteen years. On hearing through a friend about her mother's death a month ago, Saru wants to visit her father's house from where she had left as a young woman. Defying her parents to marry the man Manohar (known as diminutive Mann, a name no doubt carrying overtones of the legendary patriarchal law-giver who saw the world from a male 65 centered perspective) whom she loved. She now returned to it as a well-established doctor and a mother of two children more out of an urge to escape from the hell of life she is passing through. She appears to be confused, hopeless, dull almost thoughtless and a recluse.”(1905).

In order to escape all the ill treatment of Manu, Saru runs away to her father's home. She was unable to tolerate Manu's behaviour. Saru's father suggested her to confront the situation. She should face the problem and fight against it. This novel has an open end. Saru went to visit a patient and told Manu to wait. R. Mala comments:

The novelist's credo is to "take refuge in the self" which means that the "self" is not metaphysical but psychological. In other words, Deshpande means that the heroines will, in future, assert themselves; they will no longer allow their, "she" to get deceased. By this assertion 
of the self, Deshpande certainly takes her heroine the role of feminism through she may not have aimed at prounding any such an "ism". (56-57). 


\section{Works Cited}

Arora, Neena. Nayantara Sahgal and Dorris lessing- A Feminist Study in comparison. New Delhi: Prestige, 1991. Print.

Deshpande, Shashi. The Dark Holds No Terrors, New Delhi: Penguin, 1990.

Dhawan, R.K.Ed. Indian Women Novelists. New Delhi: Prestige Books. Set I Vol. I-IV. 1991.

Khurana, Monika. "Authentic Female Characters in the Novels of Shashi Deshpande. IJARIIE, Vol.2, 2016.

Narsimhan, Raji. Sensibility under Stress: Aspects of Indo-English Fiction. New Delhi: Ashajanak, 1976.

Ray, Mohit K and Ram Kundu. Eds. Studies in Women Writers in English. New Delhi: Atlantic Pub \& Dist. Set. I. Vol I-IV.2004.

Reddy, Sunita Y.S.A. Feminist Perspective of the Novels ofShashi Deshpande. New Delhi: Prestige Books, 2001.

Sandhu, Sarbajit K. The Image of Woman in the Novels of Shashi Deshpande. New Delhi: Prestige Books, 1991.

Sharma, Siddhartha. Shashi Deshpande's Novels A Feminist Study. New Delhi: Atlantic, 2005.

Singh, Sushila. Ed. Feminism and Recent Fiction in English. New Delhi: Prestige, 1991.

Sandhu, Sarbjit K.The Image of Woman in the Novels of Shashi Deshpande. New Delhi: Prestige Books, 1991. 